\title{
THE EFFECT OF DIGITAL ECO-LEARNING IN STUDENT WORKSHEET FLIPBOOK TO ENVIRONMENTAL PROJECT LITERACY AND PEDAGOGIC COMPETENCY
}

\author{
Sumarmi ${ }^{1}$ (D), Muhammad Aliman ${ }^{1}$ (D), Tuti Mutia ${ }^{2}$ iD \\ ${ }^{1}$ Universitas Negeri Malang (Indonesia) \\ ${ }^{2}$ Universitas Hamzanwadi (Indonesia) \\ sumarmi.ji@um.ac.id,mubammad.aliman.1607219@students.um.ac.id,mutiatia92@yahoo.co.id
}

Received December 2020

Accepted May 2021

\section{Abstract}

The study aimed to determine 1) the effect of digital eco learning in student worksheet flipbooks on environmental literacy projects, and 2) the effect of digital eco learning in student worksheet flipbooks on student ecological competence. The research is a quasi-experimental study using a Pretest-Posttest Non-equivalent Control Group. The research subjects were students in the Environmental Geography course semester 6 of 2020, divided into the experimental and control groups. The research was conducted at the Geography Education study program, Social Science Faculty, State University of Malang, Indonesia. Data were analyzed using the independent sample t-test in SPSS version 21 for windows. The results found: 1) there is a significant effect of digital eco learning with student worksheet flipbook on environmental project literacy competence, and 2) there is a significant effect of digital eco learning with student worksheet flipbooks on ecological competence. The use of digital eco-learning helps students get to know the environment quickly by using a flipbook worksheet without having to reduce their pedagogical and environmental literacy skills.

Keywords - Eco-learning, Student worksheet flipbook, Environmental project literacy, Pedagogic competency, Environmental geography.

\section{To cite this article:}

Sumarmi, Aliman, M., \& Mutia, T. (2021). The effect of digital eco-learning in student worksheet flipbook to environmental project literacy and pedagogic competency. Journal of Technology and Science Education, 11(2), 357-370. https://doi.org/10.3926/jotse.1175

\section{Introduction}

Education must teach the values of caring society to students. The issues should be part of the universities' curriculum to educate prospective teachers (Grigorov, 2012). Many things can be used for a sustainable environment, one of which is through eco-learning or environmental education. Many learning models can develop student environmental awareness, including: Earth science in community learning (earthcomm) (Aliman, Budijanto, Sumarmi, \& Astina, 2019), the effect of TREEhouse Model for experiential learning to improve environmental understanding of agricultural graduate students at Dalhousie University (Corscadden \& Kevany, 2017). Also, problem-based service learning and problembased learning can improve environmental awareness attitudes (Amin, Utaya, Bachri, Sumarmi \& Susio, 
2020; Sumarmi, Bachri, Baidowi \& Aliman, 2020). According to (Kahn, 2008), eco-learning trains students to analyze ecological issues such as global warming, floods, landslides, depletion of natural resources, poverty, and others. Environmental education aims to raise awareness, increase sensitivity and awareness to maintain the environment (Aliman et al., 2019; Sumarmi et al., 2020). Increasing students' sensitivity to the environment must be balanced with environmental literacy skills.

Current learning must include five categories of literacy skills in the 21st century: (1) Basic Literacy, such as reading, writing, and numerical calculations. (2) Computer literacy, such as skills, attitudes, and knowledge to understand and operate information and communication technology, including personal computers (PCs), laptops, and cell phones, computer literacy is divided into hardware and software. (3) Media Literacy, such as skills, attitudes, and knowledge to understand and utilize various media and information formats communicated from sender to receivers, such as images, sound, and videos. (4) Distance Learning and E-Learning Literacy, the ability to use telecommunications networks, especially the world wide web and the internet, as virtual classrooms instead of physical classrooms. (5) Cultural Literacy (United Nations Conference on Environment and Development, 1992).

Digital eco-learning with this flipbook worksheet is closely related to computer literacy, media literacy, distance learning, and e-learning literacy. Various forms of online learning are often called web-based learning (Bele \& Rugelj, 2009). Jolliffe, Ritter and Stevens (2012) as well as application or platform-based learning such as e-learning (Clark \& Mayer, 2011; Garrison, 2011), Google Classroom (Al-Maroof \& Al-Emran, 2018; Iftakhar, 2016). The Flipbook application is software that can convert files in PDF format (McBeth \& Volk, 2009). This software can input data in images, videos, music, keys, animations, and even links to other sources into one. Besides converting PDF format files, this software can convert Words, PowerPoint, and Excel with more varied output formats such as EXE, HTML, ZIP, and APP. So, it can be used on students' smartphones, laptops, and PCs. The flipbook application can be used as a medium or a tool to visualize concepts that tend to be abstract, theoretical and improve critical thinking skills (Riyanto, Amin, Suwono \& Lestari, 2020).

By developing student worksheet flipbook, it is very easy to use in eco-learning so that it can increase environmental project literacy. Eco-learning can improve ecological competence, increase awareness, knowledge, and skills in making decisions on environmental problems (Aquilina, 2001; Omran, Iraj \& Yarmohammadian, 2016). The statement is supported by research stated that environment-based learning helps students build human intelligence constructs to interact with nature by maintaining interests in going forward (Tulalessy, 2016). Other research stated that learning based on local environmental problems effectively increases students' ecological competence (Muhaimin, 2015). Eco-learning camps can also build awareness and concern for the environment, this activity, also aims to take real action in protecting the environment (Arent, Sumarmi, Utomo \& Ruja, 2020; Ghosh, 2014; Hayati, Utaya \& Astina, 2016; Napitupulu, 2015; Susanti \& Rachmawati, 2018). In addition, other research also stated that the application of flipbooks can improve students' critical thinking skills (Bozkurt \& Bozkaya, 2015; Riyanto et al., 2020).

However, research that examined digital eco-learning in students' worksheets flipbooks, environmental literacy projects, and student ecological competence has not been widely studied. Based on this statement, this study aimed to determine: 1) the effect of digital eco-learning in the student worksheet flipbook book on environmental literacy projects; 2) the effect of digital eco-learning in the student worksheet flipbook book on pedagogical competence.

\section{Theoretical Underpinnings}

Tinsley (Sumarmi, 2012) state that the development of environmental literacy projects suggested that digital eco-learning for environmental project literacy improves fieldwork skills, laboratory work, ability to collect data, organize data, analyze data, and make presentations on solving environmental problems. Environmental project literacy learning emphasizes solving authentic problems that occur daily through learning experiences in society, including environmental problems (McBeth \& Volk, 2009). The characteristics of this learning activity are long, interdisciplinary, learner-centered, and integrated with real-world issues and practices (Ghosh, 2014). 
The use of the Flipbook application to explain theoretical or abstract material is stable (Nurseto, 2011). Visualizing the Flipbook application topic can provide new learning experiences for students in the learning process (Asmi, 2018). Flipbooks can develop critical thinking skills in high school students in Indonesia (Abdurrahman, Setyaningsih \& Jalmo, 2019) and improve students' critical thinking in Indonesia (Riyanto et al., 2020). Flipped classrooms in urban general secondary students in America show increased motivation (Dixon \& Wendt, 2021). The flipped strategy also significantly improves student academic achievement in Jordan (Elian \& Hamaidi, 2018), and in Oman (Al-Maroof \& Al-Emran, 2018). Flipped classrooms also positively impact student learning performance and perceptions in Thailand (Santikarn \& Wichadee, 2018). Also, flipbooks can improve students' understanding of geography concepts (Suryani, 2015). The components of eco-learning can be seen in the following table (Grigorov, 2012; Sumarmi, 2012).

Based on Table 1, it can be explained that eco-learning is flexible learning. Eco-learning makes it easy for students to learn anywhere and anytime (Ghosh, 2014; Hayati et al., 2016). Eco-learning has a learning principle that students can still get knowledge inside and outside the classroom. Although eco-learning makes learning easier, several challenges can be a barrier for students. The project literacy challenges in eco-learning can be seen in Table 2 (Sumarmi, 2012).

\begin{tabular}{|c|l|}
\hline No & \multicolumn{1}{|c|}{ Principles and Pedagogical Strategies in Eco-learning } \\
\hline 1 & $\begin{array}{l}\text { Learning everywhere. Availability of learning materials, assignments, and results anytime and anywhere allow } \\
\text { flexibility and continuity of learning. Learning through multiple media sources to enrich demonstrations and } \\
\text { match different student learning styles. Students can edit, update, and enrich the topic. }\end{array}$ \\
\hline 2 & Students are teacher partners that actively involved in learning \\
\hline 3 & $\begin{array}{l}\text { Communication can be through in class, online synchronous, and online asynchronous. Discussions with } \\
\text { lecturers and fellow students, both about material content and project completion }\end{array}$ \\
\hline 4 & Mapping collaboration to create more effective learning \\
\hline 5 & $\begin{array}{l}\text { Lessons are carried out to achieve the project's environmental literacy. The collaborative effect in } \\
\text { asynchronous learning with peers }\end{array}$ \\
\hline 6 & $\begin{array}{l}\text { The assessment paradigm in learning self-assessment, assessment by group members, and assessment by the } \\
\text { classroom community (peer assessment). Authentic assessment is carried out on performance, resulting in } \\
\text { face-to-face, synchronous, and asynchronous }\end{array}$ \\
\hline
\end{tabular}

Table 1. Components of the Flipbook in Eco-Learning Learning

\begin{tabular}{|l|l|}
\hline \multicolumn{1}{|c|}{ Primary categories } & \multicolumn{1}{c|}{ Studying Challenges } \\
\hline Overload and stress & $\begin{array}{l}\text { Learning schedule } \\
\text { Competition in working on and completing projects } \\
\text { Communication skills } \\
\text { Pedagogical competence }\end{array}$ \\
\hline Collaborative learning & $\begin{array}{l}\text { Cooperation in groups } \\
\text { Cooperation between groups } \\
\text { Social-emotional thinking skills } \\
\text { Interdependence and reciprocity }\end{array}$ \\
\hline Change and adaptation & $\begin{array}{l}\text { Study habits } \\
\text { Technological difficulties } \\
\text { Pedagogical design } \\
\text { Motivation for active learning } \\
\text { Project the ones with the latest and contextual issues }\end{array}$ \\
\hline Learning regulation & $\begin{array}{l}\text { Organizing and planning the learning process } \\
\text { Self-discipline }\end{array}$ \\
\hline
\end{tabular}

Table 2. Challenges for Literacy Project and the Pedagogical Competencies Formation

Based on the challenges in project literacy, exercises are needed to approach the problems of eco-learning. Exercises can provide benefits for students (Riyanto et al., 2020; Sumarmi, 2012) as shown in the following Table 3. 
The application of eco-learning is expected to provide changes to students' basic competencies in improving environmental problems. Providing knowledge can change students' attitudes and skills regarding environmental problems (Aliman et al., 2019). Ecological aspects can be used to assess the understanding of the interactions between humans and the environment. Humans have a mutual relationship, are interrelated, and influence the environment (Fauzi, Muryani \& Santosa, 2018). Besides, ecological intelligence is a student competency based on the knowledge and skills related to nature which every behavior and action has an impact on the natural environment (Supriatna, 2016).

\begin{tabular}{|l|l|}
\hline \multicolumn{1}{|c|}{ Primary categories } & \multicolumn{1}{c|}{ Secondary categories } \\
\hline Learning rules & $\begin{array}{l}\text { 1. Self-learning strategies } \\
\text { 2. Learning management skills } \\
\text { 3. Learning responsibility }\end{array}$ \\
\hline $\begin{array}{l}\text { Collaboration and } \\
\text { communication }\end{array}$ & $\begin{array}{l}\text { 1. Collaboration and communication in learning } \\
\text { 2. Strategies for developing collaboration in learning } \\
\text { 3. Social-emotional management skills } \\
\text { 4. Collaboration and Communication about learning content }\end{array}$ \\
\hline $\begin{array}{l}\text { Personal and group } \\
\text { benefits }\end{array}$ & $\begin{array}{l}\text { 1. Self-development } \\
\text { 2. Knowledge and skills in using technology for material development } \\
\text { 3. Set higher-order thinking skills }\end{array}$ \\
\hline Learning & $\begin{array}{l}\text { 1. Designing better learning innovations } \\
\text { 2. Various learning methods } \\
\text { 3. Active learning } \\
\text { 4. Learning is meaningful }\end{array}$ \\
\hline
\end{tabular}

Table 3. Benefits of Digital Eco-Learning with Student Worksheet Flipbook

\section{Methodology}

\subsection{Research Subject}

The research is a quasi-experimental study using pretest-posttest non-equivalent control group design. The research subjects were students in Semester 6 of 2019/2020 consisting of two classes, class A as an experimental group of 33 people and class B as a control group of 33 people. The two classes were selected using the simple random sampling technique because they have the same learning outcomes. The research was conducted in the Environmental Geography course, in the Geography Education, Faculty of Social Science at State University of Malang, Indonesia, for 16 meetings, with 6 meetings conducted in the classroom and 10 meetings conducted through e-learning.

\subsection{Implementation}

In class A, learning was given treatment by applying a digital eco-learning model using a student worksheet flipbook. At the beginning of the meeting, students were given a pretest to determine their initial environmental project literacy and pedagogic competency skills. At the next meeting, the lecturer gave lectures through the zoom meeting application (Synchronous). Furthermore, the meeting was held asynchronously using the e-learning application (https://sipejar.um.ac.id/). Furthermore, students are guided to download worksheets through the e-learning site. The detailed activities showed in the following Figure 1.

Students are given tests related to the subject that has been studied and discussed at the final meeting. Students are also given posttests related to environmental project literacy skills and pedagogic competency for both the experimental and control groups. 


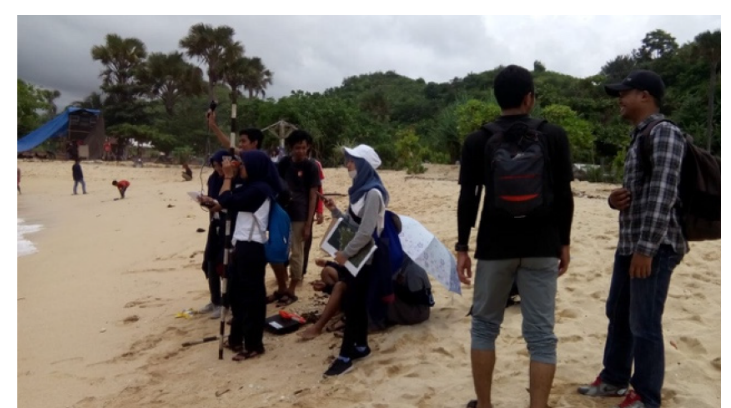

a. Identifying coastal carrying capacity

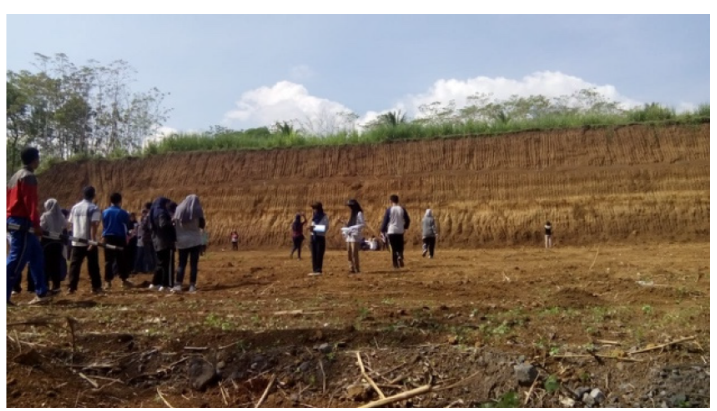

b. Identifying for possible landslides

Figure 1. Student Activity in Experiment groups

Whereas in class B, learning is carried out by applying a conventional model. In the control class, the lecturer explained the general objectives and material of the offline lecturing. At the next meeting, students made presentations and discussions following the objective in the lecturing syllabus. The detailed activities in the control group showed in the following Figure 2.

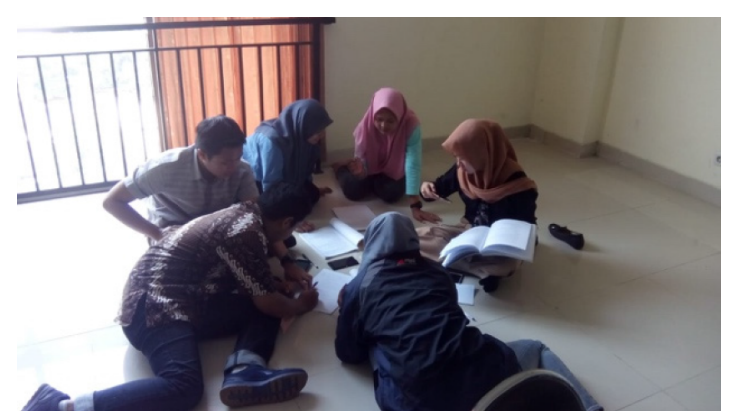

a. Discussing environmental damage

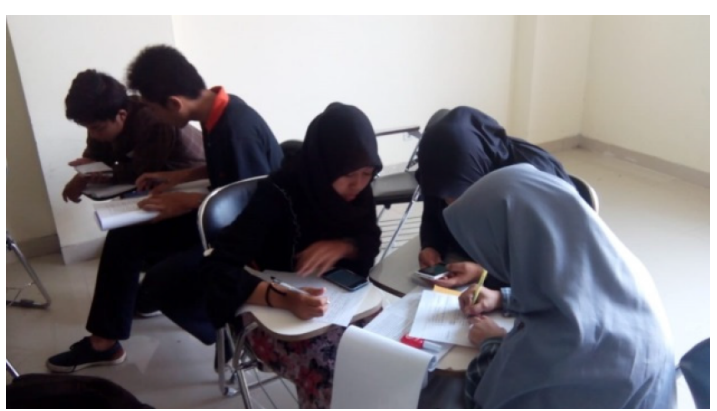

b. Designing solutions to environmental damage

Figure 2. Student Activities in Control groups

\subsection{Research Instrument}

The independent variable of this study is digital eco-learning in student worksheet flipbook, while the dependent variable is environmental project literacy and pedagogical competence. Pedagogical competence has sub-variables of ecological knowledge, ecological attitudes, and ecological skills. The instruments were used questionnaires, observation, and documentation. The following table showed criteria for environmental project literacy skills and student pedagogical abilities.

\begin{tabular}{|c|c|}
\hline Score & Criteria \\
\hline $0-20$ & Very low \\
\hline $21-40$ & Low \\
\hline $41-60$ & Moderate \\
\hline $61-80$ & High \\
\hline $81-100$ & Very high \\
\hline
\end{tabular}

Table 4. The Criteria of Literacy Project Environmental and Pedagogical Competencies

Environmental project literacy and pedagogical competence were measured using a questionnaire with 25 statements. Validity and reliability tests were carried out to collect valid data on the environmental conservation behavior questionnaire. The research instrument was tested to 37 final-year students of Geography Education study program. The instrument validity using Cronbach alpha was showed 0.986 (with the high validity category because, $0.986>0.05$ ). The result on reliability test was showed that the environmental literacy project instrument is 0.874 (with the high Reliability category because, $0.874>0.05$ ) 
and the pedagogic competency is 0.776 (with the high Reliability category because, $0.776>0.05$ ). Questions are prepared based on environmental project literacy indicators and pedagogical competencies. Documentation is data that supports research both in data and images. Research instruments of the environmental literacy project (Questions no 1-17) and pedagogic competencies (Questions no 18-25) showed in the following Table 5.

Based on the questions in Table 5, students are given options: strongly agree (4), agree (3), disagree (2), and strongly disagree (1). All answers filled in during the pretest and posttest are then added up the total value based on the environmental project literacy indicator and indicators of pedagogic competence. Then look for the average score of each indicator to find the gain score between the pretest and posttest.

\begin{tabular}{|c|c|}
\hline No & Statements \\
\hline 1 & I know the environment well. \\
\hline 2 & I know how the environment affects my life. \\
\hline 3 & I actively participate in activities that support environmental preservation. \\
\hline 4 & I can teach students to preserve the environment. \\
\hline 5 & I am constantly working to find ways to teach others about protecting the environment. \\
\hline 6 & I make time for activities to preserve the environment. \\
\hline 7 & I am doing an environmental project to conserve the surrounding environment. \\
\hline 8 & I prefer to use a spatial approach in the environmental literacy project. \\
\hline 9 & I prefer to use the environmental approach in the environmental literacy project. \\
\hline 10 & I prefer to use a complex regional approach in the environmental literacy project. \\
\hline 11 & I prefer to use the Student Worksheet Flipbook to identify data as project content about the environment. \\
\hline 12 & I prefer to use the Student Worksheet Flipbook to relate data as project content about the environment. \\
\hline 13 & I prefer to use the Student Worksheet Flipbook to analyze data as project content about the environment. \\
\hline 14 & $\begin{array}{l}\text { In this pandemic situation, I prefer to use data from the library as a data source for solving environmental } \\
\text { literacy projects. }\end{array}$ \\
\hline 15 & $\begin{array}{l}\text { In this pandemic situation, I prefer to use secondary data as a data source for the settlement of } \\
\text { environmental project literacy. }\end{array}$ \\
\hline 16 & $\begin{array}{l}\text { In this pandemic situation, I prefer to use field data as a data source for the completion of environmental } \\
\text { project literacy. }\end{array}$ \\
\hline 17 & Eco-Learning with Student Worksheet Digital is very supportive to complete my project. \\
\hline 18 & I could use geospatial data to identify environmental problems in an area. \\
\hline 19 & I could compile instructional media as a project for the study of environmental problems in an area. \\
\hline 20 & I could compile a digital Flipbook for environmental problem studies in an area. \\
\hline 21 & I could identify awareness, society, and government in the cycle of managing the environment \\
\hline 22 & $\begin{array}{l}\text { I am interested in studying environmental problems related to flash floods, river overflow floods, tidal } \\
\text { floods, mass displacement/landslides, earthquakes, tsunamis, volcanic eruptions. }\end{array}$ \\
\hline 23 & I worked on more than one project this semester. \\
\hline 24 & The completion of my first project greatly influenced the success of my second project, and so on \\
\hline 25 & Online lectures support the completion of a project that I have to work on in this pandemic situation. \\
\hline
\end{tabular}

Table 5. Environmental and Pedagogical Competence Project Literacy Questionnaire

\subsection{Data Analysis}

The data were analyzed using the independent sample t-test. Before analyzing to test the hypothesis, the normality test and homogeneity test are carried out before the hypothesis test, or prerequisite test is carried out. The normality test used the Shapiro-Wilk test to analyze the distribution of data. The homogeneity test was used to determine homogeneous data variants using Levene's test for variances equality. The hypothesis has tested using the t-test (independent sample t-test) with SPSS for windows 21.00. The analysis result is obtained from the gain score. The gain score is the difference between the 
pretest and posttest of the control and experimental groups. The gain score calculation can be seen as follows.

$$
N \text { Gain }=\frac{\text { Score Posttest }- \text { Score Pretest }}{\text { Score Ideal }- \text { Score Pretest }}
$$

\section{Results}

\subsection{Comparison Test of the Mean Gain Score between Groups}

Two groups of unpaired samples were analyzed using the independent sample T-test. Before the test, the normality assumption was tested using the Kolmogorov Smirnov test. Data that do not meet the assumptions then replaced using the Mann Whitney test. The analysis hypothesis is as follows:

$H_{0}$ : There is no significant mean gain score between groups;

$H_{1}$ : There is a significant mean gain score between groups.

Testing Criteria

- if the value $\mid \mathrm{t}$ count $\mid>\mathrm{t}$ table $(\mathrm{Z}$ count $<-\mathrm{Z}$ table, $\mathrm{Z}$ count $>\mathrm{Z}$ table), and or $\mathrm{p}$-value $<0.05$, then $\mathbf{H}_{0}$ is rejected;

- if the value $\mid \mathrm{t}$ count $\mid<\mathrm{t}$ table $\left(-\mathrm{Z}\right.$ count $<\mathrm{Z}$ table $<\mathrm{Z}$ table), and or $\mathrm{p}$-value $>0.05$, then $\mathbf{H}_{0}$ is accepted.

\subsection{Gain Score of Environmental Project Literacy}

The environmental project literacy ability of the experimental and control group was analyzed to see the mean score using the independent sample t-test analysis. Before performing the analysis, the data normality assumption test is carried out. Following are the results of the mean gain score for environmental project literacy abilities and data normality tests.

Based on Table 6, it is found that the mean gain score for the environmental literacy project control class is 9.61, lower than the experimental class of 19.70. The mean gain score between the two groups can also be seen in the pretest and posttest scores.

The results of the Kolmogorov-Smirnov normality test showed that the control and experimental group are not normally distributed because the significance value is smaller than $\alpha 5 \%$. Therefore, the data analysis was continued using the Mann-Whitney normality test. From the Mann Whitney test found Z count $<-Z$ table $(-6.413<-1.960)$, and the $\mathrm{p}$-value is smaller than $\alpha(0.000<0.050)$. Therefore, it was concluded that the hypothesis $\mathbf{H}_{0}$ was rejected. It showed a significant mean gain score between the experimental and control group based on the environmental project literacy measurement. The detail can be seen in the following Figure 3.

Based on Figure 3, the mean gain score for the environmental project literacy in the experimental group is higher than the control group. The gain score between the two groups has a difference of 10.09 , so the difference is very significant.

\begin{tabular}{|l|r|r|r|r|}
\hline \multicolumn{1}{|c|}{ Groups } & Pre & \multicolumn{1}{c|}{ Post } & Gain score & Significance of normality \\
\hline Control & 72.76 & 82.36 & 9.61 & 0.009 \\
\hline Experimental & 68.27 & 87.97 & 19.70 & 0.001 \\
\hline Z count & \multicolumn{5}{|c}{} \\
Z table (5\%) & $=1.960$ \\
p-value Z & $=0.000$ \\
\hline
\end{tabular}

Table 6. The Mean Gain score of Environmental Project Literacy 
Environmental Project Literacy Score

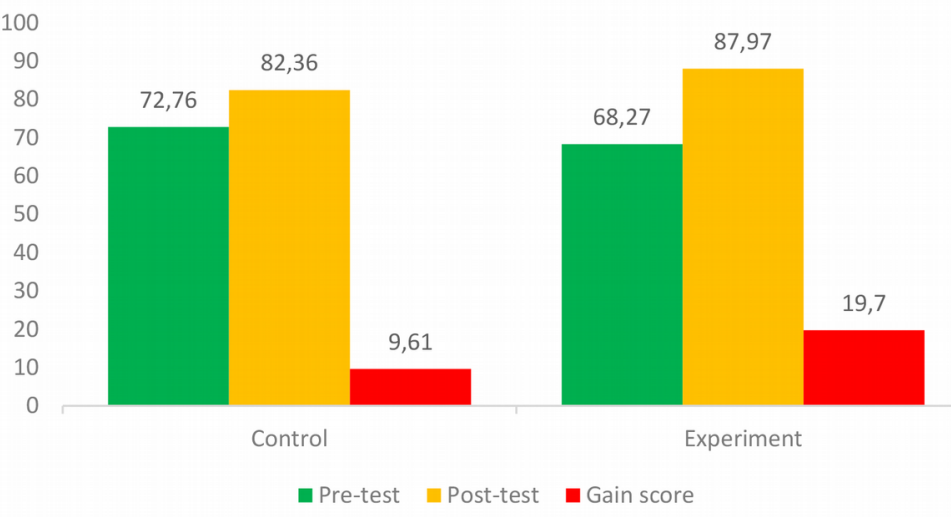

Figure 3. The Mean Gain Score of The Environmental Project Literacy

\subsection{Gain Score of Pedagogical Competency}

The students' pedagogical competence in environmental geography were analyzed using the independent sample t-test to see the mean gain score of the experimental and control group. The data normality assumption test was carried out before conducting the test on the mean gain score for student pedagogical competency. The following are the gain score results and the pedagogical competence normality test in the experimental and control group.

Based on Table 7, it is found that the mean gain score for the pedagogical competence of the control group is 7.48 , lower than the experimental group of 18.15 . The mean gain scores between the experimental and control groups can be seen from the pretest and posttest scores.

From the normality test of the Kolmogorov-Smirnov model, it was found that the experimental class was normally distributed with a significance value more than $\alpha 5 \%$, but the control class data was not normally distributed with a significance value smaller than $\alpha 5 \%$. Even though only one group of data is normally distributed, the normality assumption test is still replaced using the Mann-Whitney different test.

From the Mann Whitney test found $\mathrm{Z}$ count $<-\mathrm{Z}$ table $(-6.417<-1.960)$, and the $\mathrm{p}$-value is smaller than $\alpha(0.000<0.050)$, it was concluded that the hypothesis $\mathbf{H}_{0}$ was rejected. Therefore, there is a significant mean difference between the experimental and control groups based on the gain score of pedagogical competency. The details can be seen in the following Figure 4.

Based on Figure 4, the average gain score for the pedagogical competence in the experimental group is higher than the control group. The gain score between the two groups is 10.67 , so there is a very significant difference.

\begin{tabular}{|l|r|r|r|r|}
\hline \multicolumn{1}{|c|}{ Groups } & Pre & \multicolumn{1}{c|}{ Post } & Gain score & Significance of normality \\
\hline Control & 74.09 & 81.58 & 7.48 & 0.008 \\
\hline Experimental & 69.88 & 88.03 & 18.15 & 0.200 \\
\hline Z count & \multicolumn{5}{|c}{} \\
Z table (5\%) & $=1.960$ \\
p-value Z & & $=0.000$ & \\
\hline
\end{tabular}

Table 7. The Mean Gain Score of Pedagogical Competence 
Pedagogical Competency Score

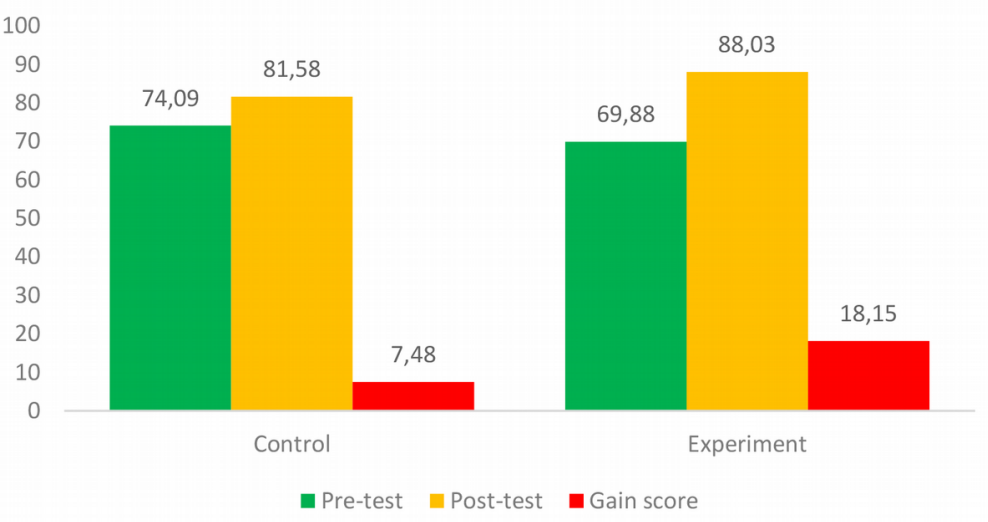

Figure 4. The Mean Gain Score for Pedagogical Competency

\section{Discussion}

\subsection{Digital Eco-Learning in the Students Worksheet Flipbook on Environmental Literacy Project}

Eco-learning is one of the contextual learning methods outside the classroom. The learning requires students to better understand their surroundings to learn through an environmental problem (Grigorov, 2012). Eco-learning encourages students to set their analytical skills in turning information into knowledge to help identify environmental problems (Muhaimin, 2015). Learning through discussions and presentations strengthens the teacher's role as a facilitator to increase activity and creativity in finding information delivered independently through cooperative learning (Bozkurt \& Bozkaya, 2015).

The group-based learning is aligned with Vygotsky's constructivism learning theory (Sumarmi, 2012). Another key to constructivist theory in learning activities is that students must find ideas, and complex information must be transformed and interpreted and turn into knowledge (Andersen \& Kjeldsen, 2015). Data from the field then analyzed, sorted, and transformed to solve problems in the students' environment. The eco-learning approach was one of the lessons that can encourage students to construct personal knowledge and skills. The eco-learning approach improves collaborative learning in small groups of students, so this approach aligns with Vygotsky's theory of social constructivism, which provided a basis for cognitive development by increasing the intensity of interpersonal interactions (Vygotsky, 1978).

The information obtained can be converted into knowledge using Eco-learning. Eco-learning can shape student attitudes, especially attitudes related to basic ecological (environmental) competencies (Ghosh, 2014; Kahn, 2008, 2010; Napitupulu, 2015). Changes in the students' ecological attitudes can be stimulated through learning Environmental Geography. The information found through learning Environmental Geography and Eco-learning leads students to analyze environmental problems. Information about environmental problems will construct student knowledge to understand environmental problems (Hayati et al., 2016). It was easier for students to find solutions and form attitudes towards a sustainable environment.

The development of knowledge, skills, and attitudes to analyze problems can be carried out through three activities, namely (1) identifying problems, resolving using prior knowledge, (2) preparing plans to solve problems, and (3) implementing prepared plans to be analyzed the process accuracy in problem-solving (Joyce \& Weil, 1996; Muhaimin, 2015).

The results showed that the eco-learning approach in Environmental Physics lectures could develop the pre-service teachers' ecological attitude by understanding the concepts of eco-physics (Napitupulu, 2015). Other research explains that pre-service teachers' ecological competence in cognitive, affective, and psychomotor can be developed through various eco-learning (Ghosh, 2014; Hayati et al., 2016).

Students' environmental literacy project skills can be improved by applying eco-learning integrated with student worksheets flipbook. The worksheet developed is concrete, simple, align with the concepts being learned so that it can build knowledge and thinking skills based on real experiences. It is also supported by 
research stated that using flipbooks can improve students' critical thinking skills (Riyanto et al., 2020). Project-based eco-learning is systematic learning that involves students in learning complex knowledge and skills, authentic questions in designing products and assignments (Baidowi, Sumarmi \& Amirudin, 2016; Sumarmi, 2012). Eco-learning with student worksheets can improve student environmental project literacy skills in solving environmental problems (Hayati et al., 2016). The environmental project emphasizes student-centered learning, while the lecturer only acts as a facilitator. Eco-learning provides opportunities for students to be active in developing knowledge that comes from environmental issues (Grigorov, 2012).

Project Literacy uses an inquiry learning strategy and uses a constructivist approach (Sumarmi, 2012). Working on the project, students will actively ask, predict, explain, and interact with concrete materials. Students use initial knowledge and apply it to new knowledge. Eco-learning creates a learning environment for students to independently construct their knowledge and skills (Grigorov, 2012; Hayati et al., 2016). Based on the research of Grant and Branch (2005), this project-based learning can; (a) develop multiple intelligences; (b) improve knowledge systems, knowledge domains, and knowledge metacognition. Metacognition includes the process of selecting, searching, asking, dividing, formulating hypotheses, and the process of making decision (Grant \& Branch, 2005). Eco-learning helps students construct knowledge independently and improves thinking skills (Ghosh, 2014; Puspitasari, Sumarmi \& Amirudin, 2016).

Eco-Learning is used to understand all environmental problems and solutions. Applying Eco-Learning helps students be sensitive to environmental problems and improve to find alternative solutions (Aliman et al., 2019; Hayati et al., 2016). The application of Eco-Learning aims to: (a) integrate the real world with learning, (b) direct student work, (c) teach collaboration or be cooperative, (d) encourage students to investigate and solve problems (Sumarmi, 2012). Eco-learning does not only develop student knowledge through the real world or environmental issues. However, eco-learning also teaches students to solve environmental problems (Garrison, 2011; Omran et al., 2016).

Eco-Learning can be applied to the geography course because it presents problems contextually in learning (Hayati et al., 2016). Eco-Learning in geography learning should: (a) raise meaningful issues to student life, (b) must raise important and new issues, (c) raise complex problems and immediate solutions, (d) problems raised must be relevant to the student, both from a pedagogical view and the student's context, (e) the problems raised should be original (Sumarmi, 2012). Eco-Learning applied in geography learning must emphasize the presentation of authentic problems (Doppelt, 2003). The problem must be following the student's environment to find appropriate solutions to environmental problems.

In the student worksheet, the literacy project uses authentic learning outcomes measurement based on performance-based assessment (Sumarmi, 2012). The learning activity consists of five stages: 1) identification of real problems, 2) planning for problem-solving strategies/alternatives, 3) product design/activity design, 4) production process/activities, and 5) evaluation using Student Worksheet flipbook presents challenges to students on environmental problems. The student worksheet also helps students provide solutions and develop literacy project skills and pedagogical competencies (Baidowi et al., 2016; Kahn, 2010).

The project is carried out in a student worksheet. The first stage is problem identification. At this stage, the thinking ability about environmental project literacy and student pedagogical competences is trained. Students must be able to identify and analyze environmental problems that occur in the surrounding environment. However, beforehand, students must understand the topic being studied by building their knowledge. It requires students to understand and be sensitive to environmental phenomena around them. The second stage is formulating strategies or alternative problem-solving. Students can provide solutions to environmental problems. The second stage is planning. At this stage, cooperation is needed for investigative activities related to the required data and information. Each group can plan activities well so that the implementation runs smoothly. The fourth stage is implementation. Students must also show good character as students and the young generation in requiring thinking skills. At this stage, students get into the community to find information. The fifth stage is evaluation. All activities carried out are then 
communicated and evaluated. Students must be open-minded to get input and suggestions for future activities.

Teachers make various evaluations to represent learners' knowledge and improve the learning process. Learning communities are developed to make students participate in environmental projects, resolve conflicts, and exchange ideas and skills. Working on a developed project is actual and meaningful, relevant to student life, and relates to the real life (Krajcik, Czerniak \& Berger, 2003). Eco-learning is used to understand environmental problems and find solutions. Finding and developing the basics of environmental ethics, understanding ecological concepts, and experiences in the field (Goodwin \& Adkins, 1997; Jenkins, 2003; Windschitl, Dvomich, Ryken, Tudor \& Koehler, 2007).

\subsection{Digital Eco-Learning in Student Worksheet Flipbook on Pedagogical Competence}

The project-based learning model is also supported by activity theory (Hung and Wong, 2000; Activity Theory) stated that the basic structure of activity consists of (a) goals to be achieved, (b) subjects in the context (c) a society as medium (d) instruments, (e) work regulations, and ( $\mathrm{f}$ ) tasks distribution. Its application in the classroom relies on learning activities that emphasize active activities (doing) rather than passive activities (receiving) knowledge from teachers. Then, digital eco-learning used can improve students' pedagogical competence.

The objectives of implementing Eco-learning are: (a) integrating learning with the real world, (b) directing students' work, (c) teaching students to collaborate, (d) Therefore, based on the objective, eco-learning can improve students' pedagogical competence. The eco-learning carried out in this study raised a significant problem for student development. Also, at the design and production process stages, students look for important, complex, new, and relevant issues from a pedagogical and contextual perspective in the environment (Supriatna, 2016). Research also supports this research stated that communication and awareness of the environment could be developed through eco-learning (Susanti \& Rachmawati, 2018). Through eco-learning that examines students' problems, students can act as the planner, collaborators, producer, decision-maker, and presenter (Audet, 2000).

Student pedagogical competence develops well by applying eco-learning. It is due to Eco-Learning principles that train students to research real problems (Blumenfeld et al, 1991). Based on eco-learning elements such as (1) introduction, (2) task description, (3) procedures for investigation, (4) learning resource support, (5) task completion mechanisms, (6) collaboration, and (7) reflection and activity transfers (Grant \& Branch, 2005). Elements in eco-learning were used to develop student pedagogical competencies and can develop student academic motivation (Dixon \& Wendt, 2021).

The student worksheets in eco-learning provided students with the knowledge and environmental sensitivity. Eco-learning shapes students' ability to analyze, synthesize, evaluate and be proficient in making decisions about the problems found. It is also aligned with previous research stated that a simultaneous and continuous environmental learning can improve the student's pedagogical environment (Aliman et al., 2019; Sumarmi et al., 2020). In addition to improving pedagogical abilities, eco-learning can also improve students' critical thinking skills (Hayati et al., 2016).

\section{Conclusions}

Based on the research and discussion results, it can be concluded that there is a significant mean gain score between the control and experimental group on environmental literacy projects and student pedagogical competence. Digital eco-learning in the student worksheet flipbook has a significant effect on student environmental literacy projects. Digital eco-learning in the student worksheet flipbook has a significant effect on student pedagogical competence. More than one person should use digital eco-learning as a control for inactive student groups. This research implies that lecturers and teachers can use this learning to improve environmental project literacy, pedagogical competency and save time. The development of digital ecolearning in the student worksheet flipbook can use other independent variables. One of the variables is critical thinking, creative thinking, and other cognitive variables. Its application can also be carried out on middle school students and pre-service teachers to determine the effectiveness. 


\section{Declaration of Conflicting Interests}

The research has no intention or conflict of interest toward individuals or groups. The research was conducted by the university students and supervised by the researcher.

\section{Funding}

The authors received no financial support for the research, authorship, and/or publication of this article.

\section{References}

Abdurrahman, A., Setyaningsih, C.A., \& Jalmo, T. (2019). Implementating Multiple Representation-Based Worksheet to Develop Critical Thinking Skills. Journal of Turkish Science Education, 16(1), 138-155.

Aliman, M., Budijanto, Sumarmi, S., \& Astina, I.K. (2019). Improving Environmental Awareness of High School Students' in Malang City through Earthcomm Learning in the Geography Class. International Journal of Instruction, 12. https://doi.org/10.29333/iji.2019.1246a

Al-Maroof, R.A.S., \& Al-Emran, M. (2018). Students Acceptance of Google Classroom: An Exploratory Study using PLS-SEM Approach. International Journal of Emerging Technologies in Learning (IJET), 13(06), 112-123. https://doi.org/10.3991/ijet.v13i06.8275

Amin, S., Utaya, S., Bachri, S., Sumarmi, S., \& Susilo, S. (2020). Effect of Problem Based Learning on Critical Thinking Skill and Enviromental Attitude. Journal for the Education of Gifted Young Scientists, 8(2), 743-755. https://doi.org/10.17478/jegys.650344

Andersen, A.S., \& Kjeldsen, T.H. (2015). A Critical Review of the Key Concepts in PPL. In Andersen, A.S., \& Heilesen, S.B. (Eds.), The Roskilde Model: Problem-Oriented Learning and Project Work (17-35). Springer International Publishing. https://doi.org/10.1007/978-3-319-09716-9_2

Aquilina, J. (2001). Environmental education policy for schools. NSW Department of Education and Training Curriculum Support Directorate.

Arent, E., Sumarmi, S., Utomo, D.H., \& Ruja, I.N. (2020). Improving students' environmental care character through Positive Character Camp (PCC) program. Journal for the Education of Gifted Young Scientists, 8(4), 1329-1343. https://doi.org/10.17478/jegys.771681

Asmi, A.R. (2018). Pengembangan E-Modul Berbasis Flipbook Maker Materi Pendidikan Karakter untuk Pembelajaran Mata Kuliah Pancasila MPK Universitas Sriwijaya. Jurnal Pendidikan Ilmu Sosial, 27, 10. https://doi.org/10.17509/jpis.v27i1.9395

Audet, J. (2000). Evaluation of Two Approaches to Entrepreneurship Education Using an Intention-based Model of Venture Creation. Academy of Entrepreneurship Journal, 6(1), 57-63.

Baidowi, A., Sumarmi, S., \& Amirudin, A. (2016). Pengaruh Model Pembelajaran Berbasis Proyek Terhadap Kemampuan Menulis Karya Ilmiah Geografi Siswa SMA. Jurnal Pendidikan Geografi, 20(1). https://doi.org/10.17977/um017v20i12015p048

Bele, J.L., \& Rugelj, J. (2009). Comparing Efficiency of Web Based Learning Contents on Different Media. International Journal of Emerging Technologies in Learning (IJET), 4(7), 31-35. https://doi.org/10.3991/ijet.v4s3.1087

Bozkurt, A., \& Bozkaya, M. (2015). Evaluation Criteria for Interactive E-Books for Open and Distance Learning. The International Review of Research in Open and Distributed Learning, 16(5). https://doi.org/10.19173/irrodl.v16i5.2218

Clark, R.C., \& Mayer, R.E. (2011). E-Learning and The Science of Instruction: Proven Guidelines for Consumers and Designers of Multimedia Learning. Pfeiffer/John Wiley \& Sons. https://doi.org/10.1002/9781118255971

Corscadden, K.W., \& Kevany, K. (2017). The TREEhouse: A hybrid model for experiential learning in environmental education. Applied Environmental Education \& Communication, 16(1), 56-67.

https://doi.org/10.1080/1533015X.2017.1282334 
Dixon, K., \& Wendt, J.L. (2021). Science Motivation and Achievement Among Minority Urban High School Students: An Examination of the Flipped Classroom Model. Journal of Science Education and Technology. https://doi.org/10.1007/s10956-021-09909-0

Doppelt, Y. (2003). Implementation and Assessment of Project-Based Learning in a Flexible Environment. International Journal of Technology and Design Education, 13(3), 255-272.

https://doi.org/10.1023/A:1026125427344

Elian, S.M., \& Hamaidi, D.A.H. (2018). The Effect of Using Flipped Classroom Strategy on the Academic Achievement of Fourth Grade Students in Jordan. International Journal of Emerging Tecbnologies in Learning (IJET), 13(02), 110-125. https://doi.org/10.3991/ijet.v13i02.7816

Fauzi, M.I., Muryani, C., \& Santosa, S. (2018). Hubungan antara Pengetahuan Lingkungan Hidup dan Prestasi Belajar Geografi dengan Sikap Peduli Lingkungan pada Siswa SMA Negeri di Kabupaten Karanganyar. GeoEco, 4(1), Article 1. https://doi.org/10.20961/ge.v4i1.19184

Garrison, D.R. (2011). E-Learning in the 21st Century: A Framework for Research and Practice. Taylor \& Francis. https://doi.org/10.4324/9780203838761

Ghosh, K. (2014). Environmental Awareness Among Secondary School Students Of Golaghat District In The State Of Assam And Their Attitude Towards Environmental Education. IOSR Journal of Humanities and Social Science, 19, 30-34. https://doi.org/10.9790/0837-19323034

Goodwin, D., \& Adkins, J. C. (1997). Problem-Solving Environmental Science on the Chesapeake Bay. School Science Review, 78(284), 49-55.

Grant, M.M., \& Branch, R.M. (2005). Project-Based Learning in a Middle School: Tracing Abilities through the Artifacts of Learning. Journal of Research on Technology in Education, 38(1), 65-98. https://doi.org/10.1080/15391523.2005.10782450

Grigorov, S. (2012). International Handbook Of Ecopedagogy for Students, Educators \& Parents. A Project for a New Eco-Sustainable Civilization. Peter Lang Pub Inc.

Hayati, W.I., Utaya, S., \& Astina, I.K. (2016). Efektivitas Student Worksheet Berbasis Project Based Learning dalam Menumbuhkan Kemampuan Berpikir Kritis Siswa Pada Mata Pelajaran Geografi. Jurnal Pendidikan: Teori, Penelitian, dan Pengembangan, 1(3), 468-474. https://doi.org/10.17977/jp.v1i3.6174

Hung, D.W.L., \& Wong, A.F.L. (2000). Activity Theory as a Framework for Project Work in Learning Environments. Educational Technology, 40(2), 33-37.

Iftakhar, S. (2016). Google Clasroom: What works and How? Journal of Education and Social Sciences, 3, 12-18.

Jenkins, M. (2003). Prospects for biodiversity. Science, 302(5648), 1175-1177. https://doi.org/10.1126/science.1088666

Jolliffe, A., Ritter, J., \& Stevens, D. (2012). The Online Learning Handbook: Developing and Using Web-based Learning. Psychology Press.

Joyce, B.R., \& Weil, M. (1996). Models of Teacbing. Allyn and Bacon.

Kahn, R. (2008). From Education for Sustainable Development to Ecopedagogy: Sustaining Capitalism or Sustaining Life? Green Theory \& Praxis: The Journal of Ecopedagogy, 4(1), 1-14.

https://doi.org/10.3903/gtp.2008.1.2

Kahn, R. (2010). Critical Pedagogy, Ecoliteracy, and Planetary Crisis: The Ecopedagogy Movement. Peter Lang Pub Inc.

Krajcik, J.S., Czerniak, C.M., \& Berger, C.F. (2003). Teaching science in elementary and middle school classrooms: Aproject-based approach. Boston, Massachusetts: Mc Graw-Hill.

McBeth, W., \& Volk, T.L. (2009). The National Environmental Literacy Project: A Baseline Study of Middle Grade Students in the United States. The Journal of Environmental Education, 41(1), 55-67. https://doi.org/10.1080/00958960903210031 
Muhaimin, M. (2015). Implementasi Model Pembelajaran Berbasis Masalah Lokal dalam Mengembangkan Kompetensi Ekologis pada Pembelajaran IPS. SOSIO-DIDAKTIKA: Social Science Education Journal, 2(1), 12-21. https://doi.org/10.15408/sd.v2i1.1409

Napitupulu, N.D. (2015). Pengembangan Sikap Ekologis Melalui Pembelajaran Ecophysics Berbasis Ecopedagogy. Jurnal Inovasi dan Pembelajaran Fisika, 2(2), 113-118. https://doi.org/10.36706/jipf.v2i2.2609

Nurseto, T. (2011). Membuat Media Pembelajaran yang Menarik. Jurnal Ekonomi Dan Pendidikan, 8(1), 19-35. https://doi.org/10.21831/jep.v811.706

Omran, M.S., Iraj, M.O., \& Yarmohammadian, M.H. (2016). Investigating the Environmental Skill, Attitude, and Knowledge of Bojnourd Islamic Azad University Students. Journal of Earth, Environment and Health Sciences, 2(1), 28-33. https://doi.org/10.4103/2423-7752.181804

Puspitasari, E., Sumarmi, S., \& Amirudin, A. (2016). Integrasi Berpikir Kritis dan Peduli Lingkungan Melalui Pembelajaran Geografi dalam Membentuk Karakter Peserta Didik SMA. Jurnal Pendidikan: Teori, Penelitian, dan Pengembangan, 1(2), 122-126. https://doi.org/10.17977/jp.v1i2.6106

Riyanto, R., Amin, M., Suwono, H., \& Lestari, U. (2020). The New Face of Digital Books in Genetic Learning: A Preliminary Development Study for Students' Critical Thinking. International Journal of Emerging Technologies in Learning (IJET), 15(10), 175-190. https://doi.org/10.3991/ijet.v15i10.14321

Santikarn, B., \& Wichadee, S. (2018). Flipping the Classroom for English Language Learners: A Study of Learning Performance and Perceptions. International Journal of Emerging Technologies in Learning (IJET), 13(09), 123-135. https://doi.org/10.3991/ijet.v13i09.7792

Sumarmi, S. (2012). Model-Model Pembelajaran Geografi. Aditya Media Publishing.

Sumarmi, S., Bachri, S., Baidowi, A., \& Aliman, M. (2020). Problem-Based Service Learning's Effect on Environmental Concern and Ability to Write Scientific Papers. International Journal of Instruction, 13(4), 161-176. https://doi.org/10.29333/iji.2020.13411a

Supriatna, N. (2016). Ecopedagogy: Membangun kecerdasan ekologis dalam Pembelajaran IPS. PT Remaja Rosdakarya. Suryani, N. (2015). Pengembangan Buku Teks Digital Interaktif untuk Pemahaman Konsep Geografi. Jurnal Geografi Gea, 15(2), Article 2. https://doi.org/10.17509/gea.v15i2.3547

Susanti, S., \& Rachmawati, T.S. (2018). Menumbuhkan Kesadaran Hidup Ekologis melalui Komunikasi Lingkungan di Eco Learning Cam. Mediator: Jurnal Komunikasi, 11(2), 188-202.

https://doi.org/10.29313/mediator.v11i2.3961

Tulalessy, Q.D. (2016). Pembelajaran Bahasa Berbasis Lingkungan sebagai Upaya Membangun Kecerdasan Ekologis. Jurnal Triton Pendidikan, 1(1), 51-56. https://doi.org/10.30862/jtp.v1i1.795

United Nations Conference on Environment and Development. (1992). Promoting Education, Public Awareness and Training. Earth Summit Report. The Report of the United Nation Conference on Environment and Development. Rio de Janeiro.

Vygotsky, L.S. (1978). Socio-cultural theory. Mind in Society, 6, 52-58.

Windschitl, M., Dvomich, K., Ryken, A.E., Tudor, M., \& Koehler, G. (2007). A comparative model of field investigations: Aligning school science inquiry with the practices of contemporary science. School Science and Mathematics, 107(1), 382-389. https://doi.org/10.1111/j.1949-8594.2007.tb17761.x

Published by OmniaScience (www.omniascience.com) Journal of Technology and Science Education, 2021 (www.jotse.org)

\section{$(1)(2)$}

Article's contents are provided on an Attribution-Non Commercial 4.0 Creative commons International License. Readers are allowed to copy, distribute and communicate article's contents, provided the author's and JOTSE journal's names are included. It must not be used for commercial purposes. To see the complete licence contents, please visit https://creativecommons.org/licenses/by-nc/4.0/. 